\title{
T Cell-Associated Immunotherapy for Hepatocellular Carcinoma
}

\author{
Weijie Ma Long Wu$^{\mathrm{a}}$ Fuling Zhou ${ }^{\mathrm{b}}$ Zhenfei Hong ${ }^{\mathrm{a}}$ Zhisu Liu ${ }^{\mathrm{a}}$ Yufeng Yuan \\ aDepartment of Hepatobiliary and Pancreatic Surgery, Zhongnan Hospital of Wuhan University, Wuhan, \\ bDepartment of Hematology, Zhongnan Hospital of Wuhan University, Wuhan, China
}

\section{Key Words}

T cellular immunotherapies $\bullet$ Hepatocellular carcinoma $\bullet$ Immune checkpoint blockade $\bullet T$ cell receptor-engineered T cells $•$ Chimeric antigen receptor-engineered T cells $•$ Bispecific T cell engagers

\begin{abstract}
Hepatocellular carcinoma (HCC) is one of the most common malignant diseases worldwide with limited therapeutic options. Accumulating evidences suggest that immunotherapy could be a promising option for treating HCC. T cell-associated immunotherapy lights up the hope for the improvement of complementary approach to conventional HCC treatments, which needs further research to consummate the clinical consequences. The present work reviewed several T cells associated cellular immunotherapies for HCC, including immune checkpoint blockade, gene-engineered T cells, bispecific T cell engagers, and so on. We also analyzed how these immunotherapies can mediate tumor cell eradication and evaluated their superiority or insufficiency.

\section{Introduction}

Hepatocellular carcinoma (HCC) ranks the sixth most common cancer and the third most common cause of cancer mortality worldwide; it has poor prognosis and limited therapeutic options [1,2]. Therefore, HCC prevention and treatment are of great concern. The progress gained from knowledge of the association between HCC and the immune system has yielded significant treatment strategy breakthroughs. Owing to the exquisitely specific immune responses, immunotherapy is dramatic and promising for the treatment of HCC [3].

The immune response is responsible for controlling nascent cancer through immunosurveillance [4]. If the early-stage micro tumors are not eradicated thoroughly by the innate or adaptive ways of immune system, then a long period of equilibrium (expansion of transformed cells is held in check by immunity) exists [5]. Eventually, the loss of tumorassociated antigens (TAAs) or decreased major histocompatibility complex (MHC) antigen 
expression, inactivation of T cells by reduced T cell receptor (TCR) signalling or interleukin (IL)-10 and transforming growth factor (TGF)- $\beta$-mediated suppression are developed. Then, a scene of immune tolerance and inactivate tumor-specific T cells caused by the above immune evasion mechanisms lead to the loss of capabilities that immune system cannot recognize TAAs and arm effective immune response against tumors [6].

T cells are suitable candidates for tumor immunotherapy to overcome these barriers and rekindle the compromised immune response of the patient against the tumors. Reports have stated that the frequencies of $\mathrm{CD}^{+} \mathrm{T}$ [7], CD4 ${ }^{+}$cytotoxic T cells [8], natural killer (NK) [9], and regulatory T (Treg) cells [10]in the tumor tissue of HCC are significantly associated with survival. $\mathrm{CD}^{+} \mathrm{T}$ cells can also efficiently promote tumor regression through their ability to secrete interleukin-2 (IL-2) [11], enhancing tumor-specific CD8+ T cells [12]. Among patients who diagnosed with HCC, CD8 ${ }^{+}$T cells respond to HCC-specific TAAs such as $\alpha$-fetoprotein (AFP), glypican-3 (GPC3), melanoma antigen gene A1 (MAGE-A1), and NY-ESO-1, which can be applied to distinguishing tumor cells from normal tissues [13]. In view of the fact that HCC is correlated with persistent hepatitis B virus (HBV) and hepatitis $\mathrm{C}$ virus (HCV) infections, viral proteins of HBV and HCV could also play a role of TAA in HCC [14]. Overexpression of APOBEC3F in tumor tissues is potentially predictive for poor recurrence-free survival from HBV-HCC patients [15]. Through RNA-sequencing and immunohistochemistry data, HCCspecific genes have been identified and validated. Two of them (namely, AKR1B10 present in the "HCV-HCC-specific" signature; IGF2BP3 common to both "HBV- and HCV-HCC-specific" signatures) which are detected not being expressed in most of normal tissues, showed a strictly HCC-specific protein expression pattern, suggesting their highly potential for HCC immunotherapy [16].

However, there still are various mechanisms considered as the factors which lead to the weak and often inefficient antitumor immune responses in HCC, such as insufficient TAA processing and presentation, the existence of immunosuppressive cell, like regulatory T cells (Treg), shortage of $\mathrm{CD}^{+}{ }^{+} \mathrm{T}$ helper cell responses and the negative regulation by PD-1/PDL1 (programmed cell death-1/ ligand for programmed cell death-1) pathway [17]. Cancersecreted TGF- $\beta 1$ may increase the quantity of Tregs and induce Treg cell polarization, therefore promoting the progression of $\operatorname{HCC}[18,19]$.

As an emerging method of tumor clearance aiming to afford more effective and selective targeting of tumor cells by recruiting or facilitating the existing tumor-specific immune response, $\mathrm{T}$ cell immunotherapy circumvents many immune evasion mechanisms. $\mathrm{T}$ cell immunotherapy for HCC has been maturing through decades' worth of effort. Various tumor immunotherapy techniques associated with T cells (Fig. 1) have been developed during the last two decades and brought excellent outcomes. The present work reviews several methods of immune modulation (Table 1) that have been explored and shown effective in suppressing HCC growth.

\section{Lymphokine-activated killer cells}

Peripheral blood leukocytes (PBL) isolated from patients with cancer and activated in vitro by IL-2, leading to the enhancement of effector cells cytotoxic to autologous fresh solid tumor cells in a manner unrestricted by MHC, were reported in the early 1980s [20]. These lymphocytes are called lymphokine-activated killer (LAK) cells. It has been reported that LAK therapy could significantly prolong the survival time of HCC patients, but failed to decrease the tumor mass [21]. Although LAK cell therapy for HCC has induced objective responses in a minority of patients [22], it produces considerable side effects simultaneously because the dose of recombinant IL-2 (rIL-2) required is usually toxic [23]. In view of the limited efficacy and increasing doubts whether LAK cells indeed cause the observed responses, the initial enthusiasm for LAK cells has waned and has been transferred to other immunotherapies. 


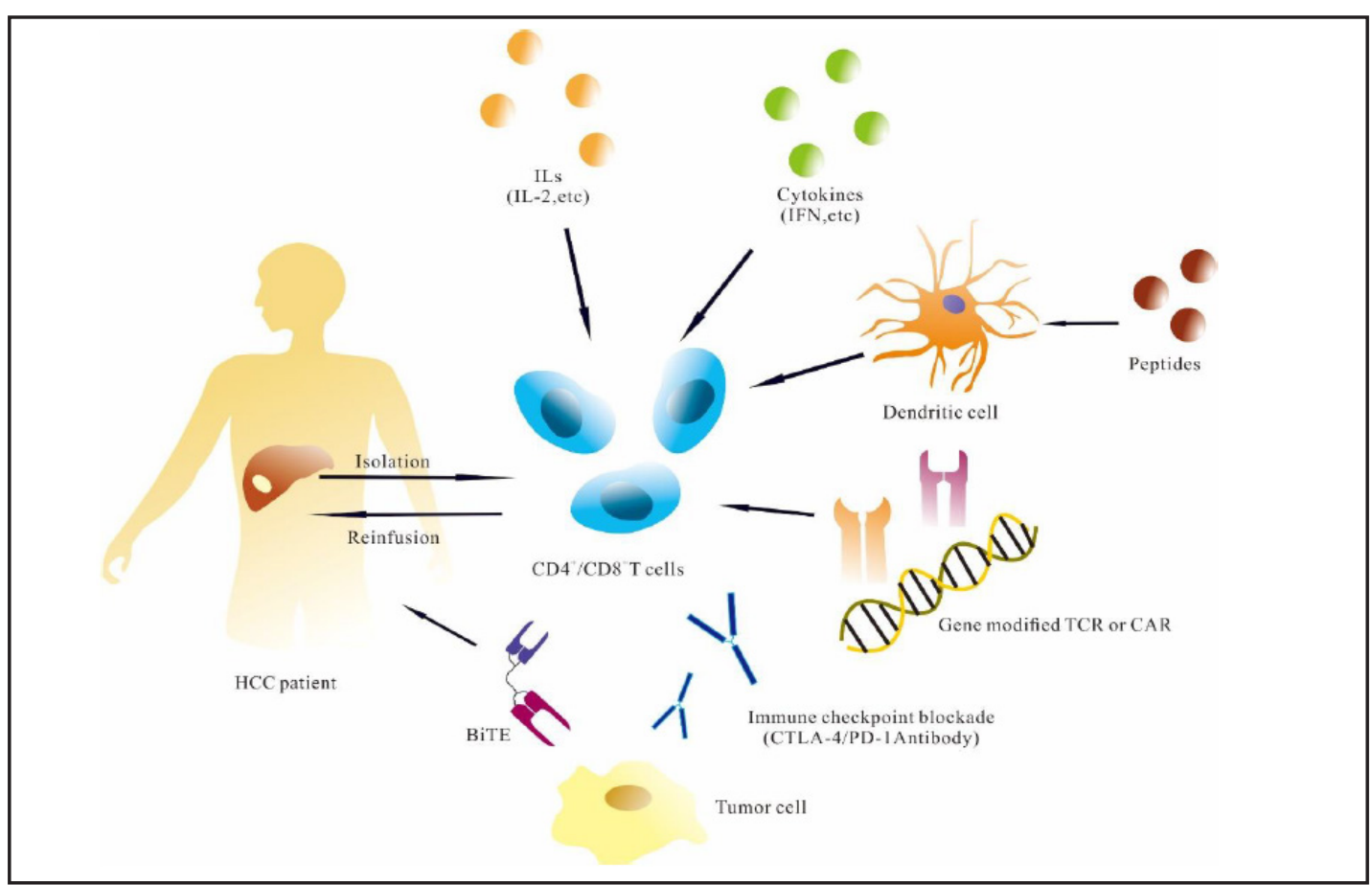

Fig. 1. The process of $\mathrm{T}$ cellular immunotherapy $\mathrm{CD} 4^{+} / \mathrm{CD} 8^{+} \mathrm{T}$ cells are isolated through patient's peripheral blood or tumor tissues, and expanded and activated with suitable doses of interleukins, cytokines or peptides ex vivo. Or, by genetic modification, these T cells are endued the specific anti-tumor activity. After expansion and alteration, certain amount of these T cells re-infused to patients to exert the function of cytotoxic for autologous tumor cell. Besides, the infusion of immune checkpoint blockade antibody or BiTE is not only working on immune cells, but also tumor cells.

\section{Tumor-infiltrating lymphocytes}

Reported in 1986, tumor-infiltrating lymphocytes (TIL) isolated from tumor samples could recognize tumors in vitro; the adoptive transfer of these syngeneic TIL, expanded in IL-2 affected the regression of established lung and liver tumors on murine tumor models [24]. TILs which play a positive role in the survival of HCC patients [25] could recognize TAAs on tumor cells and then trigger antitumor responses [26]. So, isolating, stimulating and expanding TILs in vitro from HCC patients, then infusing into the hosts could theoretically kill the tumor cells. Stefan M. Brunner, et al indicated that tumor-infiltrating, IL-33-producing effector-memory $\mathrm{CD}^{+} \mathrm{T}$ cells were independently related to prolonged HCC patient survival [27]. Clinical trials utilizing autologous TIL in patients with HCC following tumor resection have indicated that re-infusion of autologous TIL after activation and expansion in vitro can be successfully performed with low toxicity [28].

However, these therapies have limitations. These TAA specific T cells naturally exist in HCC tissues, but the antitumor ability is restricted and exhausted [29]. Let alone the enormous difficulties in the isolation TIL from HCC patients and the proliferation in vitro, only patients with good performance status who can endure the rigorous lymphodepletionand IL-2-based treatments currently used which could cause associated adverse effects are appropriate for such treatments.

\section{Cytokine-induced killer cells}

Cytokine-induced killer cells (CIK cells) are a mixture of non-MHC-restricted T lymphocytes comprising $\mathrm{CD}^{+} / \mathrm{CD}^{2} 6^{+}$cells, $\mathrm{CD} 3^{-} / \mathrm{CD}^{2} 6^{+} \mathrm{NK}$ cells, and $\mathrm{CD} 3^{+} / \mathrm{CD}^{-} 6^{-}$cytotoxic 
Table 1. Ongoing studies for T cell associated immunotherapy for Hepatocellular carcinoma

\begin{tabular}{|c|c|c|c|c|}
\hline Strategy & Clinicaltrials.gov identifier & Phase & Intervention & Status \\
\hline & NCT01462903 & 1 & Biological: tumor infiltrating lymphocytes, IL-2 & recruiting \\
\hline & NCT01174121 & 2 & $\begin{array}{l}\text { Biological: Young TIL; Drug: Aldesleukin Drug: Cyclophosphamide; Drug: Fludarabine } \\
\text { Drug: Pembrolizumab }\end{array}$ & recruiting \\
\hline \multirow[t]{4}{*}{ TIL } & NCT02315066 & 1 & Drug: PF-04518600 & recruiting \\
\hline & NCT01821482 & 2 & Biological: Dendritic and Cytokine-induced Killer Cells & Not yet recruiting \\
\hline & NCT02568748 & 3 & Biological: CIK Procedure: TACE & recruiting \\
\hline & NCT02487017 & 2 & Procedure: Transcatheter Arterial Chemoembolization(TACE) Biological: DC-CIK & recruiting \\
\hline \multirow[t]{2}{*}{ CIK } & NCT01914263 & 1 & Biological: cytokine induced killer cell & recruiting \\
\hline & NCT01868490 & 1,2 & Drug: cytokine induced killer cells & recruiting \\
\hline CTL & NCT02239861 & 1 & Biological: TAA-Specific CTLs & recruiting \\
\hline \multirow[t]{6}{*}{ TCR } & NCT02686372 & 1 & Biological: HBV antigen specific TCR redirected $\mathrm{T}$ cell & recruiting \\
\hline & NCT02719782 & 1,2 & Biological: HBV antigen specific TCR redirected T cell & recruiting \\
\hline & NCT02395250 & 1 & Biological: anti-GPC3 CAR T & recruiting \\
\hline & NCT02587689 & 1,2 & Biological: anti-MUC1 CAR T Cell & recruiting \\
\hline & NCT02723942 & 1,2 & Biological: CAR-T cell immunotherapy for GPC3 positive HCC & recruiting \\
\hline & NCT02715362 & 1,2 & Drug: TAI-GPC3-CART cells & recruiting \\
\hline \multirow[t]{2}{*}{ CAR } & NCT02905188 & 1,2 & Genetic: GLYCAR T cells; Drug: CytoxanDrug: Fludarabine & Not yet recruiting \\
\hline & NCT02959151 & 1,2 & Drug: CAR-T cell & recruiting \\
\hline
\end{tabular}

$\mathrm{T}$ cells, among which the main effector cells are $\mathrm{CD}^{+} / \mathrm{CD}^{2} 6^{+} \mathrm{T}$ cells which are rare in uncultured peripheral blood [30]. Capitalizing on patients' instinct to eradicate tumor cells via stimulation with cytokines like OKT3 monoclonal antibodies, IL-2, and interferon- $\gamma$ (IFN- $\gamma$ ), CIK cells could be converted from peripheral blood mononuclear cells (PBMCs) [31]. Compared with LAK cells, CIK cells have the characteristics of high proliferation rate, potent anti-tumor effects and minimal cytotoxicity to normal cells [32-35], these advantageous aspects render CIK cells a favorable option in cancer immunotherapy [36].

Preclinical trials have shown that CIK cells have higher anti-tumor cytotoxic activity in vitro and stronger effects on tumor growth inhibition in tumor-bearing nude mice models than LAK cells and PBMC for treating HCC [37]. In addition, co-culture with dendritic cells enhances the anti-tumor effects of CIK cells $[38,39]$. Moreover, several clinical studies chose CIK cell immunotherapy as adjuvant treatment following hepatectomy for HCC patients, indicating a significant increase in overall survival (OS) and recurrence-free survival (RFS) [34]. The median overall survival and RFS for patients who received hepatectomy and postoperative CIK cell immunotherapy were 41 and 16 months, respectively, while 28 and 12 months for the hepatectomy alone patients [40]. Besides the similar results that increased OS and RFS due to the adjuvant CIK immunotherapy, another phase 3 clinical trial has tested its efficacy and safety. Although adverse reactions, like pyrexia, chills, myalgia and fatigue were correlated to CIK cell agents in $17 \%$ of patients, they were not severe enough to delay or cease the therapy [41]. And, the combined treatment of transcatheter arterial chemoembolization (TACE) and radiofrequency ablation (RFA) with sequential CIK immunotherapy could lower the recurrence rate of HCC and prolong the RFS and OS of HCC patients without severe adverse effects $[42,43]$. However, a golden prognostic system is still needed to be established which is relevant to weighing the benefit from the adjuvant CIK cells immunotherapy [40].

\section{Cytotoxic T lymphocytes}

When TAAs are processed and presented to the MHC by antigen-presenting cells (APCs), $T$ cell activation is triggered involving two signals, one of which is from the binding of TCR to the MHC-bound antigen. Then the signals are magnified or counteracted by costimulatory molecules [4]. Cytotoxic T lymphocytes (CTLs) are CD8 $\alpha \beta$ T cells that could recognize MHC molecules, present TAAs and release granzyme B and perforin to lyse tumor cells. However, the downregulation of MHC, the existence of suppressor immune cells, like Tregs, myeloidderived suppressor cells, and the lack of costimulatory molecules restrained the effect of re-infused CTLs.

The re-activation of the immune system is considered as a crucial treatment strategy for cancers. New immunotherapy strategies such as peptide vaccines similar to TAAs have been 
attempted, and were able to stimulate T cells, causing the proliferation of effective CTLs to eliminate TAA-positive target cells. Preclinical and clinical trials have demonstrated the antitumor activity of HCC vaccines that induce peptide-specific CTL responses [44-46].

Besides that, the immune checkpoint blockade is another way. The activated immune checkpoints caused by chronic exposure to antigens could lead to T cells exhaustion and facilitate tumor evasion from host immune system [47]. The most studied immune checkpoint receptors are CTLA-4, PD-1, TIM-3, BTLA, VISTA, LAG-3 and OX40 which reduce the antigen specific immune response [48]. The blocking antibodies of CTLA-4 and PD-1 which disrupt CTLA-4/PD-1 pathways aiming to reversing exhausted T cells have already been approved by FDA for the treatment of malignancies and currently in development in HCC. The process of T cell activation needs amplified signals mediated by CD28/B7 interactions. On the contrary, CTLA-4 shares two ligands (CD80 and CD86) with CD28 and obtains stronger affinity with B7-1 and B7-2 on activated B cells and monocytes, then inhibits further costimulation [49, 50]. It has also been reported that CTLA-4 expressed on Tregs and suppressed effector T-cell activation and function [51,52]. The safety profile and antitumor and antiviral effect, have been tested by the usage of antibody, Tremelimumab $(\mathrm{CP}-675,206)$ which blocks the binding of CTLA-4, on advanced HCC with HCV-related cirrhosis [53]. The combined treatment of tremelimumab and tumor ablation for advanced HCC patients brings supporting clinical activity and causes expansion of intratumoral CD8 ${ }^{+} \mathrm{T}$ cells [54].

Similarly, PD-1 interactions with PD-L1 and PD-L2 inhibits the proliferation of T cells and restrains the release of cytokines [48]. PD-1 acts late for long-term tolerance maintenance, while CTLA-4 acts early for tolerance induction [55]. Tumor cells expressed PD-L1 or PDL2 could evade the elimination of immune system by PD-L1/PD-1 signal pathway which stimulates PD-1 in TILs [48]. The drastically increased expression of PD-1 was found on tumor infiltrating $\mathrm{CD}^{+} \mathrm{T}$ cells in HCC and related with poorer disease progression and postoperative relapse. Moreover, by blocking PD-L1, CD8 ${ }^{+} \mathrm{T}$ cells apoptosis was reversed [56]. Therefore, inhibiting PD-1/PD-L1 pathway may enhance the efficacy of therapy. Phase I clinical trials blocking PD-1/PD-L1 in cancer patients with various malignancies have shown promising results $[57,58]$. Blocking PD-1/PD-L1 which is expressed at high level on T cells from tumor and liver than peripheral blood from HCC patients increased the frequency of tumor-specific T cells in HCC patients [59]. PD-1/PD-L1 blockade could increase the immune response of vaccine-induced GPC3-specific CTLs, therefore enhance the antitumor effects of a GPC3 peptide vaccine for HCC [60]. Several clinical trials with PD-1 blockade for advanced HCC patients is under recruiting. Recently, Calderaro, et al. detected that PDL1 expression by either neoplastic or intratumoral inflammatory cells was associated with tumor aggressiveness which suggested that PD-L1/PD-1 immune checkpoint blockade might be efficacious only in a subgroup of HCC patients and limited to particular HCC variants [61]. Therefore, the various tumor subtypes should be taken into account in the subsequent clinical trials, which could better illustrate the anti-tumor efficacy of PD-L1/PD-1 immune checkpoint blockade.

Realizing the great effect of immune checkpoint blockade, more and more researchers believe that anti-tumor effectiveness could be enhanced through combinatorial approaches. Recently, a clinical trial is under recruiting to evaluate the effectiveness, safety and tolerability of Nivolumab and the combination Nivolumab and Ipilimumab in patients with advanced HCC (NCT01658878).

\section{T cell receptor-engineered $\mathrm{T}$ cell immunotherapy}

Via their T cell receptor, T cells can respond to TAAs occasionally. A commonly observed mechanism of tumor immune tolerance caused by reduction of major MHC antigens [62] usually impairs the ability of T cells to respond to tumor antigens throughout the lifetime of an individual, therefore presenting a major challenge to isolating tumor-specific $\mathrm{T}$ cells from most patients with cancer. 


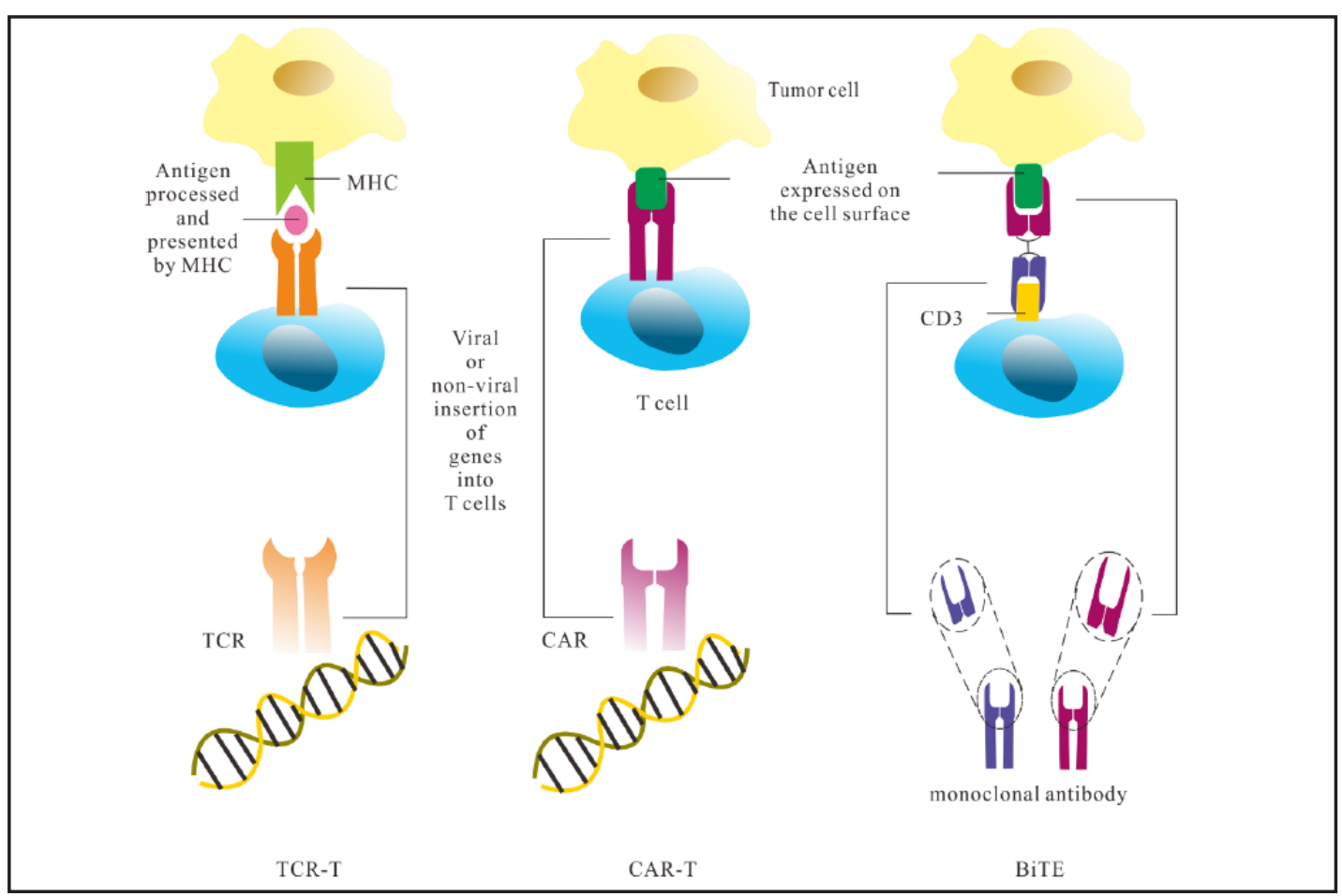

Fig. 2. The comparison of TCR, CAR and BiTE Genetic engineering techniques can be applied to introduce antitumor receptors into normal T cells. (a)The above image show that insertion of a conventional TCR and CAR into a patient's T lymphocytes, followed by the expansion and infusion back into the patient. TCR is composed of one $\alpha$ chain and one $\beta$ chain, and they recognize antigens that have been processed and presented by the patient's own MHC molecules. The CAR is composed of linked V chains from a TAA-specific monoclonal antibody, bound to a spacer arm from the hinge region of IgG or from the CD8 receptor. This then attaches to a CD28 transmembrane domain (TM), costimulation molecule (such as OX-40, 4-1BB) and cytoplasmic domain which is composed of the $\mathrm{CD} 3 \zeta$ signaling element. The gene modified CAR is inserted into $\mathrm{CD}^{+} / \mathrm{CD}^{+} \mathrm{T}$ cells isolated from PBMC of patients to obtain the tumor specific CAR-T cells which can recognize TAA presented on the tumor cell surface. (b)BiTEs consist of two ScFvs originating from two separate mAbs; one ScFv recognizes a tumor antigen, while the other is specified for CD3 $\varepsilon$ on T cells. A small fusion linker connects both variable fragments. Both arms of BiTE must be bound to mediate tumor cytotoxicity.

Fortunately, through genetic engineering, T cells could be endowed with the capacity to be reactive against tumors (Fig. 2). TCR genes which consist of $\alpha$ - and $\beta$-chains united with the $\gamma^{-}, \delta-, \varepsilon-$, and $\zeta$-chains of the CD3 complex are derived from tumor-specific T cells, and they could encode cell surface receptors which can recognize TAAs. These TCR genes obtained from humans or the immunization of human leukocyte antigen (HLA) transgenic mice that express human MHC, alternatively, can be generated in bacteriophages that bind to tumor peptide antigens [63]. When a tumor antigen peptide fragment presented on the tumor cell MHC is encountered by TCR, the phosphorylation of immunoreceptor tyrosinebased activation motifs (ITAMs) happens, following an intracellular signaling cascade causing the release of cytokines and cytotoxic compounds from T cells [64].

There are many applications of TCRs in HCC (see more details in Table 2) [65-71]. TCR genes endow T cells with tumor-specific responses [66]. TCR therapy had been applied on the HBV-related HCC, as the close relationship between HCC and HBV infection and high level of HBV integrations in HBV-related HCC tumors [72]. Adam J. Gehring, et al demonstrated that TCR re-directed HBV-specific T cells derived from PBMC of chronic HBV and HBV-related HCC patients through retroviral transduction, had the capabilities of recognizing HBVinfected cells and HCC tumor cells expressing viral antigens from naturally integrated HBV DNA [65]. To overcome the deficiencies of the viral vectors, like underlying risk of oncogene 


\section{Cellular Physiology Cell Physiol Biochem 2017;41:609-622

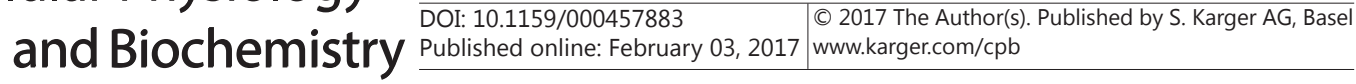 \\ Ma et all: T Cell-Associated Immunotherapy}

Table 2. Several studies of TCR immunotherapy

\begin{tabular}{|c|c|c|c|c|c|c|c|}
\hline $\begin{array}{l}\text { Antigens } \\
\text { targeted }\end{array}$ & Study & Restriction & Construction of TCR & Source of T cells & T cell type & transduction & Tirals \\
\hline \multirow{4}{*}{ HBV } & $\begin{array}{l}\text { Gehring et al. } \\
\text { [65] }\end{array}$ & HLA-A2 & $\begin{array}{l}\text { HBc18-27 specific TCR; HBs183-91-speciffic } \\
\text { TCR (s183-TCR); HBsAg370-79, (s370-TCR) }\end{array}$ & $\begin{array}{l}5 \text { healthy controls and } 10 \text { chronic HBV } \\
\text { patients, } 5 \text { HBV-related HCC patients }\end{array}$ & $\mathrm{CD} 8+\mathrm{T}$ cells & Retrovirus & in vitro \\
\hline & Koh et al. [66] & HLA-A2 & HBV s183-91-specific TCR (s183-TCR) & 5 healthy donors & $\mathrm{CD} 8+\mathrm{T}$ cells & Electroporation & $\begin{array}{l}\text { in vitro \& } \\
\text { in vivo }\end{array}$ \\
\hline & Qasim et al. [67] & HLA-A2 & HBV s183-91-specific TCR (s183-TCR) & $\begin{array}{l}1 \text { paitent with } \mathrm{HCC} \text { relapse } 10 \text { years } \\
\text { following liver transplantation for } \\
\mathrm{HBV}+\mathrm{HCC}\end{array}$ & $\begin{array}{l}\text { autologous T } \\
\text { cells }\end{array}$ & Retrovirus & Clinical \\
\hline & $\begin{array}{l}\text { Bertoletti et al. } \\
\text { [71] }\end{array}$ & $\begin{array}{l}\text { HLA- } \\
\text { A0201 }\end{array}$ & HLA-A0201/HBs183-91-specific TCR & $\begin{array}{l}1 \mathrm{HBV} \text { related HCC patient with } \\
\text { extrahepatic HCC metastasis }\end{array}$ & $\begin{array}{l}\text { autologous T } \\
\text { cells }\end{array}$ & Electroporation & Clinical \\
\hline $\mathrm{HCV}$ & Zhang et al. [68] & HLA-A2 & HCV NS3:1073-1081 TCR & $\begin{array}{l}\text { 1 patient with a } \\
\text { chronic HCV infection }\end{array}$ & $\begin{array}{l}\text { CD4+ and CD8+ } \\
\text { T cells }\end{array}$ & Retrovirus & in vitro \\
\hline GPC3 & Dargel et al. [69] & HLA-A2 & Glypican-3367 Specific T-Cell Receptor P1-1 & 1 healthy HLA-A2 negative donor & $\mathrm{CD} 8+\mathrm{T}$ cells & Retrovirus & $\begin{array}{l}\text { in vitro \& } \\
\text { in vivo }\end{array}$ \\
\hline AFP & Sun et al. [70] & HLA-A2 & AFP158-166-specific TCR transgenetic CTLS & HLA-A*02:01 positive healthy donors & $\mathrm{CD} 8+\mathrm{T}$ cells & Lentivirus & $\begin{array}{l}\text { in vitro \& } \\
\text { in vivo }\end{array}$ \\
\hline
\end{tabular}

activation $[73,74]$, Sarene Koh, et al endowed T cells with an antigen-specific functionality by mRNA electroporation, these transiently expressing anti-HBV TCR could have efficient anti-HCC activity in vitro and a xenograft model of HCC, despite the transient functionality [66]. Furthermore, Antonio Bertoletti, et al applied the engineered HBV-TCR-T cells on a HBVrelated HCC patient who had a liver transplant and then with extrahepatic HCC metastasis with HBV-DNA integration [71]. These re-infused HBV-TCR-T cells dramatically decreased the level of HBsAg in the patient, while, unfortunately, no detectable reduction of the volume of the HCC metastasis [71]. While, the HBV antigen might be expressed on the non-tumor hepatocytes, not exclusively on the tumor cells and this adoptive TCR modified HBV-specific T cells may trigger severe liver damage [66]. Now, limited knowledge on HBV integrations and antigen expression in HBV-related HCC and whether HBV integrations preferentially occur in HBV-infected hepatocytes or transformed/cancerous hepatocytes. Thus, the potential efficacy of TCR immunotherapy specific for HBV-related HCC patients should be considered in the future studies. Besides, the restriction of a specific HLA molecule for TCR-T cell to recognize the target antigen processed within the cytoplasm and presented on the surface of cancer cells, TCR immunotherapy should be improved in a wide range [75].

\section{Chimeric antigen receptor-engineered $\mathbf{T}$ cell immunotherapy}

Chimeric antigen receptors (CARs) arm T cells with ability of recognizing defined antigen specifically and permiting T cell targeting of specified tumor cell. Connected by single-chain variable regions $(\mathrm{ScFv})$ of monoclonal antibody heavy and light chains that can identify the TAA and T cell signal transduction zone, CAR-T cells can distinguish an overexpressed tumor cell surface antigen directly.

The extracellular antigen-binding domain, the transmembrane domain, and the cytoplasmic signaling domain are the three main domains of a CAR. The signal sequence of costimulatory molecules may facilitate the proliferation of $\mathrm{T}$ cells and prevent activationinduced cell death (AICD) and T cell depletion [76]. In the application of CD20-CAR-T cell treatment of relapsed indolent B cell lymphoma or mantle cell lymphoma clinical trials, first-generation CAR-T cells which only fused CD3 $\zeta$ or Fc receptors as the signal domain did not obtain significant anti-tumor abilities, in vivo proliferation, or persistence [77]. To make improvements, one or more costimulatory molecules, like CD28, CD134 (OX-40), and CD137 (4-1BB) are fused to CD3Z[78]. The so-called second generation CAR contains two signaling domains and the third-generation contains additional ones. Both of them have the advantage of cytokine production and proliferation in vitro, and mediate tumor regression in xenograft models in NOD/SCID/ZC (NSG) mice in comparison with the first-generation CAR-T cells [79].

Another key point of CARs is the selection of tumor-specific antigen (TSA), which is not significantly expressed in normal tissues. Unfortunately, most currently defined tumor antigens are TAAs that are not expressed in vital tissues or have relatively higher expression in tumor cells than normal cells. However, TAA expression in normal tissues varies; therefore, 
CAR-modified immune cells that attack the tumor tissues will also cause damage to normal tissues or organs. In one case, a female patient who received human epidermal growth factor receptor 2 (HER2)/neu-specific CAR-T cell immunotherapy died from off-target toxicity that caused cytokine storm and subsequent organ failure [80].

The success of CAR-T cells in treating CD19-positive hematological malignancies have spurred interest in their application to solid tumors [81-83]. Recently, several studies selected GPC3 as a HCC TAA $[69,84,85]$. Gao H, et al and Li W, et al constructed CAR-T cells that could specifically target GPC3 on the surface of HCC cells, as the attempts to apply CAR-T cell immunotherapy for the treatment in HCC, which showed significant anti-tumor activity both in vitro and in vivo [84, 85]. CAR-T cells specific for HBV envelope proteins localized to liver in mice which reduced HBV replication with transient liver damage [86]. These ignited the hope for treating HBV related HCC patients in a non-HLA limited way.

Unlike TCRs, CARs can overcome the restriction of MHC, but still face the problem of safety and insertional mutagenesis. The shortage of appropriate TAA as described above, the inefficient homing of $\mathrm{T}$ cells to tumor sites, and the immunosuppressive microenvironment of solid tumors has largely impeded the success of CARs in the context of solid tumors [87].

\section{Bispecific T cell engagers}

Derived from the bispecific antibodies composed of two ScFvs, one that recognizes a TAA and another that binds CD3 on T cells [88], bispecific T cell engagers (BiTEs) have been proven as highly efficient $\mathrm{T}$ cell recruiters for tumor immunotherapy. BiTE-mediated cytotoxicity occurs only when CD3 and the TAA are both bound by BiTE, theoretically eliciting a polyclonal $\mathrm{T}$ cell response towards target tumor cells [89] which could be largely indispensable for conventional $\mathrm{T}$ cell recognition molecules like MHC class I molecules and costimulatory proteins [90]. BiTE could recruit and activate $\mathrm{T}$ cells resulting in the raising of the characteristic activation markers CD69 and CD25 and the secretion of cytokines [91, 92]. Moreover, the perforin-mediated delivery of granzyme B causes the calcium-dependent proteolytic activation of intracellular caspases leading to death of tumor cells [93, 94].

Blinatumomab (MT103), a CD19/CD3-targeting BiTE, has been approved in the US by the FDA for treating acute lymphocytic leukemia (ALL) recently. As the first tested BiTE in humans, clinical trials have demonstrated its safety and efficacy in treating hematological malignancy [95]. Targeting epithelial cell adhesion molecule (Ep-CAM), frequently overexpressed in most human carcinomas while having limited accessibility to normal epithelial tissues [96], the Ep-CAM-specific BiTE (MT110) has the potential to be applied in various human carcinomas. The great results of use of BiTE in hematologic malignancies and solid tumors, like pancreatic tumor $[97,98]$. These good jobs explored the potential of BiTE and encouraged the passion of applying BiTE to treat HCC. Recently, an assay has detected the efficacy of anti-EpCAM BiTE 1H8/CD3 in HCC treatment in vitro and in vivo experiments [99].

Other than the similarity to CAR-T cells, namely independence of MHC and tumor specificity, BiTEs can not only reactivate T cells within tumor microenvironments [100], but can also convert Treg cell immunosuppression into tumor-directed cytotoxicity [101]. However, considerable clinical trials are needed to confirm the practical anti-tumor efficacy of BiTE in solid tumors including HCC.

\section{Conclusions}

T cell associated immunotherapies combined with cytokines, vaccines, and antibodies has achieved significant anti-tumor activity. Although much work have been carried out, the clinical results in solid tumors remain unsatisfactory, as previously reported [87]. Owing to the immune escape and the dearth of specific tumor antigens, only a proportion of $\mathrm{T}$ cells can 


\section{Cellular Physiology Cell Physiol Biochem 2017;41:609-622

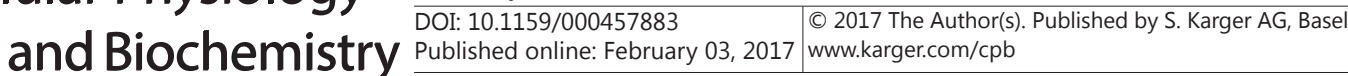 \\ Ma et all: T Cell-Associated Immunotherapy}

exert the full anti-tumor function. Decades of improvement have aided the development of T cell immunotherapy. The distinct advances of each strategy could be utilized to exploit better $\mathrm{T}$ cell immunotherapies in a wide range of carcinomas, including HCC. T cell immunotherapy could act as an effective therapy which would reduce the rate of relapse, improve the quality of life, and prolong survival in the near future.

\section{Disclosure Statement}

No conflict of interest.

\section{References}

1 Lafaro KJ, Demirjian AN, Pawlik TM: Epidemiology of hepatocellular carcinoma. Surg Oncol Clin N Am 2015;24:1-17.

-2 Fong ZV, Tanabe KK: The clinical management of hepatocellular carcinoma in the United States, Europe, and Asia: a comprehensive and evidence-based comparison and review. Cancer 2014;120:2824-2838.

-3 Butterfield LH: Immunotherapeutic strategies for hepatocellular carcinoma. Gastroenterology 2004;127:S232-241.

4 Schreiber RD, Old LJ, Smyth MJ: Cancer immunoediting: integrating immunity's roles in cancer suppression and promotion. Science 2011;331:1565-1570.

-5 Koebel CM, Vermi W, Swann JB, Zerafa N, Rodig SJ, Old LJ, Smyth MJ, Schreiber RD: Adaptive immunity maintains occult cancer in an equilibrium state. Nature 2007;450:903-907.

-6 Marr LA, Gilham DE, Campbell JD, Fraser AR: Immunology in the clinic review series; focus on cancer: double trouble for tumours: bi-functional and redirected T cells as effective cancer immunotherapies. Clin Exp Immunol 2012;167:216-225.

7 Sun C, Xu J, Song J, Liu C, Wang J, Weng C, Sun H, Wei H, Xiao W, Sun R, Tian Z: The predictive value of centre tumour CD8(+) T cells in patients with hepatocellular carcinoma: comparison with Immunoscore. Oncotarget 2015;6:35602-35615.

8 Fu J, Zhang Z, Zhou L, Qi Z, Xing S, Lv J, Shi J, Fu B, Liu Z, Zhang JY, Jin L, Zhao Y, Lau GK, Zhao J, Wang FS: Impairment of CD4+ cytotoxic T cells predicts poor survival and high recurrence rates in patients with hepatocellular carcinoma. Hepatology 2013;58:139-149.

-9 Cariani E, Pilli M, Barili V, Porro E, Biasini E, Olivani A, Dalla Valle R, Trenti T, Ferrari C, Missale G: Natural killer cells phenotypic characterization as an outcome predictor of HCV-linked HCC after curative treatments. Oncoimmunology 2016;5:e1154249.

10 Zhou L, Fu JL, Lu YY, Fu BY, Wang CP, An LJ, Wang XZ, Zeng Z, Zhou CB, Yang YP, Wang FS: Regulatory T cells are associated with post-cryoablation prognosis in patients with hepatitis B virus-related hepatocellular carcinoma. J Gastroenterol 2010;45:968-978.

-11 Antony PA, Piccirillo CA, Akpinarli A, Finkelstein SE, Speiss PJ, Surman DR, Palmer DC, Chan CC, Klebanoff CA, Overwijk WW, Rosenberg SA, Restifo NP: CD8+ T cell immunity against a tumor/self-antigen is augmented by CD4+ T helper cells and hindered by naturally occurring T regulatory cells. J Immunol 2005;174:2591-2601.

12 Pardoll DM, Topalian SL: The role of CD4+ T cell responses in antitumor immunity. Curr Opin Immunol 1998;10:588-594.

13 Flecken T, Schmidt N, Hild S, Gostick E, Drognitz O, Zeiser R, Schemmer P, Bruns H, Eiermann T, Price DA, Blum HE, Neumann-Haefelin C, Thimme R: Immunodominance and functional alterations of tumorassociated antigen-specific CD8+ T-cell responses in hepatocellular carcinoma. Hepatology 2014;59:14151426.

14 Ilan Y: Immune therapy for hepatocellular carcinoma. Hepatol Int 2014;8:499-504.

15 Yang Z, Zhuang L, Yu Y, Zhou W, Lu Y, Xu Q Tang B, Chen X: Overexpression of APOBEC3F in tumor tissues is potentially predictive for poor recurrence-free survival from HBV-related hepatocellular carcinoma. Discov Med 2015;20:349-356. 


\section{Cellular Physiology Cell Physiol Biochem 2017;41:609-622

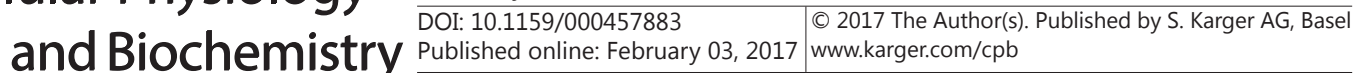 \\ Ma et all: T Cell-Associated Immunotherapy}

16 Petrizzo A, Caruso FP, Tagliamonte M, Tornesello ML, Ceccarelli M, Costa V, Aprile M, Esposito R, Ciliberto G, Buonaguro FM, Buonaguro L: Identification and Validation of HCC-specific Gene Transcriptional Signature for Tumor Antigen Discovery. Sci Rep 2016;6:29258.

$\checkmark 17$ Breous E, Thimme R: Potential of immunotherapy for hepatocellular carcinoma. J Hepatol 2011;54:830834.

18 Wang Y, Liu T, Tang W, Deng B, Chen Y, Zhu J, Shen X: Hepatocellular Carcinoma Cells Induce Regulatory T Cells and Lead to Poor Prognosis via Production of Transforming Growth Factor-beta1. Cell Physiol Biochem 2016;38:306-318.

19 Shen Y, Wei Y, Wang Z, Jing Y, He H, Yuan J, Li R, Zhao Q, Wei L, Yang T, Lu J: TGF-beta regulates hepatocellular carcinoma progression by inducing Treg cell polarization. Cell Physiol Biochem 2015;35:1623-1632.

20 Grimm EA, Mazumder A, Zhang HZ, Rosenberg SA: Lymphokine-activated killer cell phenomenon. Lysis of natural killer-resistant fresh solid tumor cells by interleukin 2-activated autologous human peripheral blood lymphocytes. J Exp Med 1982;155:1823-1841.

21 Bertelli R, Neri F, Tsivian M, Ruhrman N, Cavallari G, Beltempo P, Puviani L, DeVinci C, Pizza G, Nardo B: Endolymphatic immunotherapy in inoperable hepatocellular carcinoma. Transplant Proc 2008;40:19131915.

22 Okuno K, Takagi H, Nakamura T, Nakamura Y, Iwasa Z, Yasutomi M: Treatment for unresectable hepatoma via selective hepatic arterial infusion of lymphokine-activated killer cells generated from autologous spleen cells. Cancer 1986;58:1001-1006.

23 Lotze MT, Matory YL, Rayner AA, Ettinghausen SE, Vetto JT, Seipp CA, Rosenberg SA: Clinical effects and toxicity of interleukin-2 in patients with cancer. Cancer 1986;58:2764-2772.

-24 Rosenberg SA, Spiess P, Lafreniere R: A new approach to the adoptive immunotherapy of cancer with tumor-infiltrating lymphocytes. Science 1986;233:1318-1321.

25 Chew V, Tow C, Teo M, Wong HL, Chan J, Gehring A, Loh M, Bolze A, Quek R, Lee VK, Lee KH, Abastado JP, Toh HC, Nardin A: Inflammatory tumour microenvironment is associated with superior survival in hepatocellular carcinoma patients. J Hepatol 2010;52:370-379.

26 Gajewski TF, Schreiber H, Fu YX: Innate and adaptive immune cells in the tumor microenvironment. Nat Immunol 2013;14:1014-1022.

-27 Brunner SM, Rubner C, Kesselring R, Martin M, Griesshammer E, Ruemmele P, Stempfl T, Teufel A, Schlitt HJ, Fichtner-Feigl S: Tumor-infiltrating, interleukin-33-producing effector-memory CD8(+) T cells in resected hepatocellular carcinoma prolong patient survival. Hepatology 2015;61:1957-1967.

28 Jiang SS, Tang Y, Zhang YJ, Weng DS, Zhou ZG, Pan K, Pan QZ, Wang QJ, Liu Q He J, Zhao JJ, Li J, Chen MS, Chang AE, Li Q, Xia JC: A phase I clinical trial utilizing autologous tumor-infiltrating lymphocytes in patients with primary hepatocellular carcinoma. Oncotarget 2015;6:41339-41349.

-29 Li KK, Adams DH: Antitumor CD8+ T cells in hepatocellular carcinoma: present but exhausted. Hepatology 2014;59:1232-1234.

30 Schmidt-Wolf IG, Lefterova P, Mehta BA, Fernandez LP, Huhn D, Blume KG, Weissman IL, Negrin RS: Phenotypic characterization and identification of effector cells involved in tumor cell recognition of cytokine-induced killer cells. Exp Hematol 1993;21:1673-1679.

-31 Schmidt-Wolf IG, Negrin RS, Kiem HP, Blume KG, Weissman IL: Use of a SCID mouse/human lymphoma model to evaluate cytokine-induced killer cells with potent antitumor cell activity. J Exp Med 1991;174:139-149.

-32 Jiang J, Wu C, Lu B: Cytokine-induced killer cells promote antitumor immunity. J Transl Med 2013;11:83.

-33 Alvarnas JC, Linn YC, Hope EG, Negrin RS: Expansion of cytotoxic CD3+ CD56+ cells from peripheral blood progenitor cells of patients undergoing autologous hematopoietic cell transplantation. Biol Blood Marrow Transplant 2001;7:216-222.

34 Sangiolo D: Cytokine induced killer cells as promising immunotherapy for solid tumors. J Cancer 2011;2:363-368.

-35 Nishimura R, Baker J, Beilhack A, Zeiser R, Olson JA, Sega EI, Karimi M, Negrin RS: In vivo trafficking and survival of cytokine-induced killer cells resulting in minimal GVHD with retention of antitumor activity. Blood 2008;112:2563-2574. 


\section{Cellular Physiology Cell Physiol Biochem 2017;41:609-622 \begin{tabular}{ll|l|l|l} 
DOI: 10.1159/000457883 & 2017 The Author(s). Published by S. Karger AG, Basel \\
and Biochemistry & Published onine: Feoruary 03, 2017 & www.karger.com/cpb
\end{tabular}

-36 Mesiano G, Todorovic M, Gammaitoni L, Leuci V, Giraudo Diego L, Carnevale-Schianca F, Fagioli F, Piacibello W, Aglietta M, Sangiolo D: Cytokine-induced killer (CIK) cells as feasible and effective adoptive immunotherapy for the treatment of solid tumors. Expert Opin Biol Ther 2012;12:673-684.

-37 Wang FS, Liu MX, Zhang B, Shi M, Lei ZY, Sun WB, Du QY, Chen JM: Antitumor activities of human autologous cytokine-induced killer (CIK) cells against hepatocellular carcinoma cells in vitro and in vivo. World J Gastroenterol 2002;8:464-468.

38 Gonzalez-Carmona MA, Marten A, Hoffmann P, Schneider C, Sievers E, Schmidt-Wolf IG, Sauerbruch T, Caselmann WH: Patient-derived dendritic cells transduced with an a-fetoprotein-encoding adenovirus and co-cultured with autologous cytokine-induced lymphocytes induce a specific and strong immune response against hepatocellular carcinoma cells. Liver Int 2006;26:369-379.

39 Wang Y, Wang Y, Mu H, Liu T, Chen X, Shen Z: Enhanced specific antitumor immunity of dendritic cells transduced with the glypican 3 gene and co-cultured with cytokine-induced killer cells against hepatocellular carcinoma cells. Mol Med Rep 2015;11:3361-3367.

40 Pan QZ, Wang QJ, Dan JQ, Pan K, Li YQ, Zhang YJ, Zhao JJ, Weng DS, Tang Y, Huang LX, He J, Chen SP, Ke ML, Chen MS, Wicha MS, Chang AE, Zeng YX, Li Q, Xia JC: A nomogram for predicting the benefit of adjuvant cytokine-induced killer cell immunotherapy in patients with hepatocellular carcinoma. Sci Rep 2015;5:9202.

41 Lee JH, Lee JH, Lim YS, Yeon JE, Song TJ, Yu SJ, Gwak GY, Kim KM, Kim YJ, Lee JW, Yoon JH: Adjuvant immunotherapy with autologous cytokine-induced killer cells for hepatocellular carcinoma. Gastroenterology 2015;148:1383-1391 e1386.

42 Huang ZM, Li W, Li S, Gao F, Zhou QM, Wu FM, He N, Pan CC, Xia JC, Wu PH, Zhao M: Cytokine-induced killer cells in combination with transcatheter arterial chemoembolization and radiofrequency ablation for hepatocellular carcinoma patients. J Immunother 2013;36:287-293.

-43 Cui J, Wang N, Zhao H, Jin H, Wang G, Niu C, Terunuma H, He H, Li W: Combination of radiofrequency ablation and sequential cellular immunotherapy improves progression-free survival for patients with hepatocellular carcinoma. Int J Cancer 2014;134:342-351.

44 Sawada Y, Yoshikawa T, Nobuoka D, Shirakawa H, Kuronuma T, Motomura Y, Mizuno S, Ishii H, Nakachi K, Konishi M, Nakagohri T, Takahashi S, Gotohda N, Takayama T, Yamao K, Uesaka K, Furuse J, Kinoshita T, Nakatsura T: Phase I trial of a glypican-3-derived peptide vaccine for advanced hepatocellular carcinoma: immunologic evidence and potential for improving overall survival. Clin Cancer Res 2012;18:3686-3696.

45 Yutani S, Ueshima K, Abe K, Ishiguro A, Eguchi J, Matsueda S, Komatsu N, Shichijo S, Yamada A, Itoh K, Sasada T, Kudo M, Noguchi M: Phase II Study of Personalized Peptide Vaccination with Both a Hepatitis C Virus-Derived Peptide and Peptides from Tumor-Associated Antigens for the Treatment of HCV-Positive Advanced Hepatocellular Carcinoma Patients. J Immunol Res 2015;2015:473909.

46 Liu Y, Butterfield LH, Fu X, Song Z, Zhang X, Lu C, Ding G, Wu M: Lentivirally engineered dendritic cells activate AFP-specific T cells which inhibit hepatocellular carcinoma growth in vitro and in vivo. Int J Oncol 2011;39:245-253.

47 Jiang Y, Li Y, Zhu B: T-cell exhaustion in the tumor microenvironment. Cell Death Dis 2015;6:e1792.

48 Hato T, Goyal L, Greten TF, Duda DG, Zhu AX: Immune checkpoint blockade in hepatocellular carcinoma: current progress and future directions. Hepatology 2014;60:1776-1782.

49 Qureshi OS, Zheng Y, Nakamura K, Attridge K, Manzotti C, Schmidt EM, Baker J, Jeffery LE, Kaur S, Briggs Z, Hou TZ, Futter CE, Anderson G, Walker LS, Sansom DM: Trans-endocytosis of CD80 and CD86: a molecular basis for the cell-extrinsic function of CTLA-4. Science 2011;332:600-603.

-50 Buchbinder E, Hodi FS: Cytotoxic T lymphocyte antigen-4 and immune checkpoint blockade. J Clin Invest 2015;125:3377-3383.

51 Tang Q, Boden EK, Henriksen KJ, Bour-Jordan H, Bi M, Bluestone JA: Distinct roles of CTLA-4 and TGF-beta in CD4+CD25+ regulatory T cell function. Eur J Immunol 2004;34:2996-3005.

52 Wing K, Onishi Y, Prieto-Martin P, Yamaguchi T, Miyara M, Fehervari Z, Nomura T, Sakaguchi S: CTLA-4 control over Foxp3+ regulatory T cell function. Science 2008;322:271-275.

-53 Sangro B, Gomez-Martin C, de la Mata M, Inarrairaegui M, Garralda E, Barrera P, Riezu-Boj JI, Larrea E, Alfaro C, Sarobe P, Lasarte JJ, Perez-Gracia JL, Melero I, Prieto J: A clinical trial of CTLA-4 blockade with tremelimumab in patients with hepatocellular carcinoma and chronic hepatitis C. J Hepatol 2013;59:81-88. 


\section{Cellular Physiology Cell Physiol Biochem 2017;41:609-622 and Biochemistry DOI: 10.1159/000457883 2010 (0) 2017 The Author(s). Published by S. Karger AG, Basel \\ Ma et all: T Cell-Associated Immunotherapy}

54 Duffy AG, Ulahannan SV, Makorova-Rusher O, Rahma O, Wedemeyer H, Pratt D, Davis JL, Hughes MS, Heller T, ElGindi M, Uppala A, Korangy F, Kleiner DE, Figg WD, Venzon D, Steinberg SM, Venkatesan AM, Krishnasamy V, Abi-Jaoudeh N, Levy E, Wood BJ, Greten TF: Tremelimumab in Combination with Ablation in Patients with Advanced Hepatocellular Carcinoma. J Hepatol DOI:10.1016/j.jhep.2016.10.029.

55 Fife BT, Bluestone JA: Control of peripheral T-cell tolerance and autoimmunity via the CTLA-4 and PD-1 pathways. Immunol Rev 2008;224:166-182.

56 Shi F, Shi M, Zeng Z, Qi RZ, Liu ZW, Zhang JY, Yang YP, Tien P, Wang FS: PD-1 and PD-L1 upregulation promotes CD8(+) T-cell apoptosis and postoperative recurrence in hepatocellular carcinoma patients. Int J Cancer 2011;128:887-896.

-57 Brahmer JR, Tykodi SS, Chow LQ, Hwu WJ, Topalian SL, Hwu P, Drake CG, Camacho LH, Kauh J, Odunsi K, Pitot HC, Hamid O, Bhatia S, Martins R, Eaton K, Chen S, Salay TM, Alaparthy S, Grosso JF, Korman AJ, Parker SM, Agrawal S, Goldberg SM, Pardoll DM, Gupta A, Wigginton JM: Safety and activity of anti-PD-L1 antibody in patients with advanced cancer. N Engl J Med 2012;366:2455-2465.

58 Topalian SL, Hodi FS, Brahmer JR, Gettinger SN, Smith DC, McDermott DF, Powderly JD, Carvajal RD, Sosman JA, Atkins MB, Leming PD, Spigel DR, Antonia SJ, Horn L, Drake CG, Pardoll DM, Chen L, Sharfman WH, Anders RA, Taube JM, McMiller TL, Xu H, Korman AJ, Jure-Kunkel M, Agrawal S, McDonald D, Kollia GD, Gupta A, Wigginton JM, Sznol M: Safety, activity, and immune correlates of anti-PD-1 antibody in cancer. N Engl J Med 2012;366:2443-2454.

59 Gehring AJ, Ho ZZ, Tan AT, Aung MO, Lee KH, Tan KC, Lim SG, Bertoletti A: Profile of tumor antigenspecific CD8 T cells in patients with hepatitis B virus-related hepatocellular carcinoma. Gastroenterology 2009;137:682-690.

-60 Sawada Y, Yoshikawa T, Shimomura M, Iwama T, Endo I, Nakatsura T: Programmed death-1 blockade enhances the antitumor effects of peptide vaccine-induced peptide-specific cytotoxic T lymphocytes. Int J Oncol 2015;46:28-36.

-61 Calderaro J, Rousseau B, Amaddeo G, Mercey M, Charpy C, Costentin C, Luciani A, Zafrani ES, Laurent A, Azoulay D, Lafdil F, Pawlotsky JM: Programmed death ligand 1 expression in hepatocellular carcinoma: Relationship With clinical and pathological features. Hepatology 2016;64:2038-2046.

-62 Elkord E, Dangoor A, Burt DJ, Southgate TD, Daayana S, Harrop R, Drijfhout JW, Sherlock D, Hawkins RE, Stern PL: Immune evasion mechanisms in colorectal cancer liver metastasis patients vaccinated with TroVax (MVA-5T4). Cancer Immunol Immunother 2009;58:1657-1667.

63 Zhao Y, Bennett AD, Zheng Z, Wang QJ, Robbins PF, Yu LY, Li Y, Molloy PE, Dunn SM, Jakobsen BK, Rosenberg SA, Morgan RA: High-affinity TCRs generated by phage display provide CD4+ T cells with the ability to recognize and kill tumor cell lines. J Immunol 2007;179:5845-5854.

64 Kershaw MH, Westwood JA, Darcy PK: Gene-engineered T cells for cancer therapy. Nat Rev Cancer 2013;13:525-541.

65 Gehring AJ, Xue SA, Ho ZZ, Teoh D, Ruedl C, Chia A, Koh S, Lim SG, Maini MK, Stauss H, Bertoletti A: Engineering virus-specific T cells that target HBV infected hepatocytes and hepatocellular carcinoma cell lines. J Hepatol 2011;55:103-110.

66 Koh S, Shimasaki N, Suwanarusk R, Ho ZZ, Chia A, Banu N, Howland SW, Ong AS, Gehring AJ, Stauss H, Renia L, Sallberg M, Campana D, Bertoletti A: A practical approach to immunotherapy of hepatocellular carcinoma using T cells redirected against hepatitis B virus. Mol Ther Nucleic Acids 2013;2:e114.

67 Qasim W, Brunetto M, Gehring AJ, Xue SA, Schurich A, Khakpoor A, Zhan H, Ciccorossi P, Gilmour K, Cavallone D, Moriconi F, Farzhenah F, Mazzoni A, Chan L, Morris E, Thrasher A, Maini MK, Bonino F, Stauss H, Bertoletti A: Immunotherapy of HCC metastases with autologous T cell receptor redirected T cells, targeting HBsAg in a liver transplant patient. J Hepatol 2015;62:486-491.

68 Zhang Y, Liu Y, Moxley KM, Golden-Mason L, Hughes MG, Liu T, Heemskerk MH, Rosen HR, Nishimura MI: Transduction of human T cells with a novel T-cell receptor confers anti-HCV reactivity. PLoS Pathog 2010;6:e1001018.

69 Dargel C, Bassani-Sternberg M, Hasreiter J, Zani F, Bockmann JH, Thiele F, Bohne F, Wisskirchen K, Wilde S, Sprinzl MF, Schendel DJ, Krackhardt AM, Uckert W, Wohlleber D, Schiemann M, Stemmer K, Heikenwalder M, Busch DH, Richter G, Mann M, Protzer U: T Cells Engineered to Express a T-Cell Receptor Specific for Glypican-3 to Recognize and Kill Hepatoma Cells In Vitro and in Mice. Gastroenterology 2015;149:10421052. 


\section{Cellular Physiology Cell Physiol Biochem 2017;41:609-622 \begin{tabular}{l|l|l} 
and Biochemistry $10.1159 / 000457883$ & $\begin{array}{l}\text { C } 2017 \text { The Author(s). Published by S. Karger AG, Basel } \\
\text { www.karger.com/cpb }\end{array}$ \\
\hline
\end{tabular}

70 Sun L, Guo H, Jiang R, Lu L, Liu T, He X: Engineered cytotoxic T lymphocytes with AFP-specific TCR gene for adoptive immunotherapy in hepatocellular carcinoma. Tumour Biol 2016;37:799-806.

71 Bertoletti A, Brunetto M, Maini MK, Bonino F, Qasim W, Stauss H: T cell receptor-therapy in HBV-related hepatocellularcarcinoma. Oncoimmunology 2015;4:e1008354.

72 Sung WK, Zheng H, Li S, Chen R, Liu X, Li Y, Lee NP, Lee WH, Ariyaratne PN, Tennakoon C, Mulawadi FH, Wong KF, Liu AM, Poon RT, Fan ST, Chan KL, Gong Z, Hu Y, Lin Z, Wang G, Zhang Q Barber TD, Chou WC, Aggarwal A, Hao K, Zhou W, Zhang C, Hardwick J, Buser C, Xu J, Kan Z, Dai H, Mao M, Reinhard C, Wang J, Luk JM: Genome-wide survey of recurrent HBV integration in hepatocellular carcinoma. Nat Genet 2012;44:765-769.

73 Recchia A, Bonini C, Magnani Z, Urbinati F, Sartori D, Muraro S, Tagliafico E, Bondanza A, Stanghellini MT, Bernardi M, Pescarollo A, Ciceri F, Bordignon C, Mavilio F: Retroviral vector integration deregulates gene expression but has no consequence on the biology and function of transplanted T cells. Proc Natl Acad Sci U S A 2006;103:1457-1462.

74 Hacein-Bey-Abina S, Garrigue A, Wang GP, Soulier J, Lim A, Morillon E, Clappier E, Caccavelli L, Delabesse E, Beldjord K, Asnafi V, MacIntyre E, Dal Cortivo L, Radford I, Brousse N, Sigaux F, Moshous D, Hauer J, Borkhardt A, Belohradsky BH, Wintergerst U, Velez MC, Leiva L, Sorensen R, Wulffraat N, Blanche $\mathrm{S}$, Bushman FD, Fischer A, Cavazzana-Calvo M: Insertional oncogenesis in 4 patients after retrovirusmediated gene therapy of SCID-X1. J Clin Invest 2008;118:3132-3142.

-75 Corrigan-Curay J, Kiem HP, Baltimore D, O'Reilly M, Brentjens RJ, Cooper L, Forman S, Gottschalk S, Greenberg P, Junghans R, Heslop H, Jensen M, Mackall C, June C, Press O, Powell D, Ribas A, Rosenberg S, Sadelain M, Till B, Patterson AP, Jambou RC, Rosenthal E, Gargiulo L, Montgomery M, Kohn DB: T-cell immunotherapy: looking forward. Mol Ther 2014;22:1564-1574.

76 van der Stegen SJ, Hamieh M, Sadelain M: The pharmacology of second-generation chimeric antigen receptors. Nat Rev Drug Discov 2015;14:499-509.

-77 Till BG, Jensen MC, Wang J, Chen EY, Wood BL, Greisman HA, Qian X, James SE, Raubitschek A, Forman SJ, Gopal AK, Pagel JM, Lindgren CG, Greenberg PD, Riddell SR, Press OW: Adoptive immunotherapy for indolent non-Hodgkin lymphoma and mantle cell lymphoma using genetically modified autologous CD20specific T cells. Blood 2008;112:2261-2271.

78 Jensen MC, Riddell SR: Designing chimeric antigen receptors to effectively and safely target tumors. Curr Opin Immunol 2015;33:9-15.

79 Imai C, Mihara K, Andreansky M, Nicholson IC, Pui CH, Geiger TL, Campana D: Chimeric receptors with 4-1BB signaling capacity provoke potent cytotoxicity against acute lymphoblastic leukemia. Leukemia 2004;18:676-684.

80 Morgan RA, Yang JC, Kitano M, Dudley ME, Laurencot CM, Rosenberg SA: Case report of a serious adverse event following the administration of $\mathrm{T}$ cells transduced with a chimeric antigen receptor recognizing ERBB2. Mol Ther 2010;18:843-851.

81 Grupp SA, Kalos M, Barrett D, Aplenc R, Porter DL, Rheingold SR, Teachey DT, Chew A, Hauck B, Wright JF, Milone MC, Levine BL, June $\mathrm{CH}$ : Chimeric antigen receptor-modified T cells for acute lymphoid leukemia. $\mathrm{N}$ Engl J Med 2013;368:1509-1518.

82 Brentjens RJ, Riviere I, Park JH, Davila ML, Wang X, Stefanski J, Taylor C, Yeh R, Bartido S, Borquez-Ojeda O, Olszewska M, Bernal Y, Pegram H, Przybylowski M, Hollyman D, Usachenko Y, Pirraglia D, Hosey J, Santos E, Halton E, Maslak P, Scheinberg D, Jurcic J, Heaney M, Heller G, Frattini M, Sadelain M: Safety and persistence of adoptively transferred autologous CD19-targeted T cells in patients with relapsed or chemotherapy refractory B-cell leukemias. Blood 2011;118:4817-4828.

83 Kochenderfer JN, Dudley ME, Feldman SA, Wilson WH, Spaner DE, Maric I, Stetler-Stevenson M, Phan GQ, Hughes MS, Sherry RM, Yang JC, Kammula US, Devillier L, Carpenter R, Nathan DA, Morgan RA, Laurencot C, Rosenberg SA: B-cell depletion and remissions of malignancy along with cytokine-associated toxicity in a clinical trial of anti-CD19 chimeric-antigen-receptor-transduced T cells. Blood 2012;119:2709-2720.

84 Gao H, Li K, Tu H, Pan X, Jiang H, Shi B, Kong J, Wang H, Yang S, Gu J, Li Z: Development of T cells redirected to glypican-3 for the treatment of hepatocellular carcinoma. Clin Cancer Res 2014;20:6418-6428.

85 Li W, Guo L, Rathi P, Marinova E, Gao X, Wu MF, Liu H, Dotti G, Gottschalk S, Metelitsa LS, Heczey A: Redirecting T Cells to Glypican-3 with 4-1BB Zeta Chimeric Antigen Receptors Results in Th1 Polarization and Potent Antitumor Activity. Hum Gene Ther 2016;10.1089/hum.2016.025 


\section{Cellular Physiology Cell Physiol Biochem 2017;41:609-622

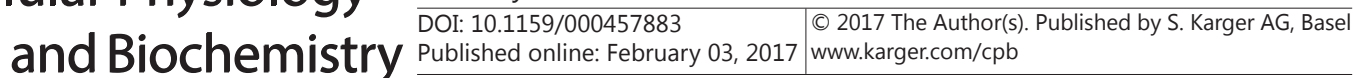 \\ Ma et all: T Cell-Associated Immunotherapy}

-86 Krebs K, Bottinger N, Huang LR, Chmielewski M, Arzberger S, Gasteiger G, Jager C, Schmitt E, Bohne F, Aichler M, Uckert W, Abken H, Heikenwalder M, Knolle P, Protzer U: T cells expressing a chimeric antigen receptor that binds hepatitis $B$ virus envelope proteins control virus replication in mice. Gastroenterology 2013;145:456-465.

87 Kakarla S, Gottschalk S: CAR T cells for solid tumors: armed and ready to go? Cancer J 2014;20:151-155.

-88 Wolf E, Hofmeister R, Kufer P, Schlereth B, Baeuerle PA: BiTEs: bispecific antibody constructs with unique anti-tumor activity. Drug Discov Today 2005;10:1237-1244.

89 Nagorsen D, Kufer P, Baeuerle PA, Bargou R: Blinatumomab: a historical perspective. Pharmacol Ther 2012;136:334-342.

-90 Offner S, Hofmeister R, Romaniuk A, Kufer P, Baeuerle PA: Induction of regular cytolytic T cell synapses by bispecific single-chain antibody constructs on MHC class I-negative tumor cells. Mol Immunol 2006;43:763-771.

-91 Choi BD, Kuan CT, Cai M, Archer GE, Mitchell DA, Gedeon PC, Sanchez-Perez L, Pastan I, Bigner DD, Sampson JH: Systemic administration of a bispecific antibody targeting EGFRvIII successfully treats intracerebral glioma. Proc Natl Acad Sci U S A 2013;110:270-275.

92 Brandl C, Haas C, d'Argouges S, Fisch T, Kufer P, Brischwein K, Prang N, Bargou R, Suzich J, Baeuerle PA, Hofmeister R: The effect of dexamethasone on polyclonal $\mathrm{T}$ cell activation and redirected target cell lysis as induced by a CD19/CD3-bispecific single-chain antibody construct. Cancer Immunol Immunother 2007;56:1551-1563.

-93 Browne KA, Blink E, Sutton VR, Froelich CJ, Jans DA, Trapani JA: Cytosolic delivery of granzyme B by bacterial toxins: evidence that endosomal disruption, in addition to transmembrane pore formation, is an important function of perforin. Mol Cell Biol 1999;19:8604-8615.

-94 Haas C, Krinner E, Brischwein K, Hoffmann P, Lutterbuse R, Schlereth B, Kufer P, Baeuerle PA: Mode of cytotoxic action of T cell-engaging BiTE antibody MT110. Immunobiology 2009;214:441-453.

-95 Nagorsen D, Baeuerle PA: Immunomodulatory therapy of cancer with T cell-engaging BiTE antibody blinatumomab. Exp Cell Res 2011;317:1255-1260.

-96 Momburg F, Moldenhauer G, Hammerling GJ, Moller P: Immunohistochemical study of the expression of a Mr 34,000 human epithelium-specific surface glycoprotein in normal and malignant tissues. Cancer Res 1987;47:2883-2891.

-97 Cioffi M, Dorado J, Baeuerle PA, Heeschen C: EpCAM/CD3-Bispecific T-cell engaging antibody MT110 eliminates primary human pancreatic cancer stem cells. Clin Cancer Res 2012;18:465-474.

-98 d'Argouges S, Wissing S, Brandl C, Prang N, Lutterbuese R, Kozhich A, Suzich J, Locher M, Kiener P, Kufer P, Hofmeister R, Baeuerle PA, Bargou RC: Combination of rituximab with blinatumomab (MT103/MEDI-538), a T cell-engaging CD19-/CD3-bispecific antibody, for highly efficient lysis of human B lymphoma cells. Leuk Res 2009;33:465-473.

-99 Zhang P, Shi B, Gao H, Jiang H, Kong J, Yan J, Pan X, Li K, Zhang P, Yao M, Yang S, Gu J, Wang H, Li Z: An EpCAM/CD3 bispecific antibody efficiently eliminates hepatocellular carcinoma cells with limited galectin-1 expression. Cancer Immunol Immunother 2014;63:121-132.

100 Baeuerle PA, Kufer P, Bargou R: BiTE: Teaching antibodies to engage T-cells for cancer therapy. Curr Opin Mol Ther 2009;11:22-30.

101 Choi BD, Gedeon PC, Sanchez-Perez L, Bigner DD, Sampson JH: Regulatory T cells are redirected to kill glioblastoma by an EGFRvIII-targeted bispecific antibody. Oncoimmunology 2013;2:e26757. 